\title{
Short-term effects in canopy gap area on the recovery of compacted soil caused by forest harvesting in old-growth Oriental beech (Fagus orientalis Lipsky) stands
}

\author{
Meghdad Jourgholami ${ }^{(1)}$, \\ Jahangir Feghhi ${ }^{(1)}$, \\ Farzam Tavankar ${ }^{(2)}$, \\ Francesco Latterini ${ }^{(3)}$, \\ Rachele Venanzi ${ }^{(4)}$, \\ Rodolfo Picchio ${ }^{(4)}$
}

\section{Introduction}

Forest soil is an important component of forest ecosystems. It has a remarkable capacity for regulating organic matter and nutrient cycling. Minerals, organic substances, and well aerated porous struc tures are the promoting factors (Marchi et al. 2018). The wide range of macro- and mi-

\begin{abstract}
Natural treefall gaps have a substantial role in maintaining soil and plant diversity in old-growth forests. However, the amount of information on the effects of gaps on the recovery of physical and chemical properties of compacted soils is scarce. We tested the hypothesis that natural treefall gaps accelerate the restoration of compacted soil by enhancing biological and microbial activity in the topsoil after a period of five years. Five years after a ground-based skidding operation in the Hyrcanian forest, the recovery levels of soil properties were compared among different treatments including natural canopy gaps with an area of $200 \mathrm{~m}^{2}$ (NCG), clear-cuts with an area of $1600 \mathrm{~m}^{2}$ (CC), disturbed trails under a dense canopy (DDC), and an undisturbed area (UND) as control. The lowest soil bulk density $\left(1.07 \mathrm{~g} \mathrm{~cm}^{-3}\right)$, penetration resistance $(1.11 \mathrm{MPa})$, and the highest macroporosity (36.3\%), and sand content $(14.4 \%)$ among treatments were recorded for the NCG followed by DDC and CC treatments. Significantly lower values of soil $\mathrm{pH}$, and electric conductivity and the highest values of soil organic $\mathrm{C}$, total $\mathrm{N}$, available $\mathrm{P}, \mathrm{K}, \mathrm{Ca}$, and $\mathrm{Mg}$ were detected under the NCG followed by the DDC and CC treatments, as compared to the UND area. The highest values of earthworm density and dry mass, and soil microbial respiration were found in the NCG followed by the DDC and CC treatments. Fine root biomass was significantly higher in the UND area $\left(92.27 \mathrm{~g} \mathrm{~m}^{-2}\right)$ followed by the DDC, NCG and CC treatments. We can conclude that the effects of gap size on the recovery values of compacted soil were significant in terms of greater nutrient availability and higher earthworm density and dry mass, suggesting that mimicking natural canopy gap was more effective than the clear-cut gap (CC) for the resilience of the forest stand in the restoration of soil quality.
\end{abstract}

Keywords: Canopy Gap Area, Timber Extraction, Skid Trails, Soil Compaction, Forest Soil Recovery, Earthworm, Hyrcanian Forest

cro-organisms in forest soil with these promoting factors leads to a higher recycling rate of nutrients and better functioning of the ecosystem, which results in an increase in forest productivity (Cambi et al. 2015, Jourgholami et al. 2019).

The use of heavy machinery in logging operations can potentially lead to soil distur-
(1) Department of Forestry and Forest Economics, Faculty of Natural Resources, University of Tehran, Alborz, Karaj (Iran); (2) Department of Forestry, Khalkhal Branch, Islamic Azad University (Iran); (3) Consiglio per la Ricerca in Agricoltura e l'Analisi dell'Economia Agraria CREA, Centro di Ricerca Ingegneria e Trasformazioni Agroalimentari, v. della Pascolare 16, I-00015 Monterotondo, RM (Italy); (4) Department of Agricultural and Forest Sciences, University of Tuscia, I-01100 Viterbo (Italy)

@ Meghdad Jourgholami (mjgholami@ut.ac.ir)

Received: Apr 02, 2020 - Accepted: Jun 20, 2021

Citation: Jourgholami M, Feghhi J, Tavankar F, Latterini F, Venanzi R, Picchio R (2021). Shortterm effects in canopy gap area on the recovery of compacted soil caused by forest harvesting in old-growth Oriental beech (Fagus orientalis Lipsky) stands. iForest 14: 370-377. doi: 10.3832/ifor3432-014 [online 2021-08-10]

Communicated by: Angelo Nolè bance and compaction, hence, efforts must be made to mitigate the negative ecological effects on forest soil from the point of view of sustainable forest operation (SFO) and sustainable forest management (SFM - Marchi et al. 2018). Air-filled pores in the surface soil were found to be destroyed after machine traffic on the skid trails due to ground-based logging operations (Merino et al. 1998, Picchio et al. 2012), leading to an increase in soil bulk density (Cambi et al. 2015, Jourgholami et al. 2019, Picchio et al. 2019a), decreasing total porosity (Meyer et al. 2014, Klaes et al. 2016), and mixing of the mineral and organic horizons (Jourgholami et al. 2019). Moreover, both abiotic and biotic components such as soil microbial populations of forest soil are affected by soil compaction caused by machinery traffic after forest harvesting operations (Marchi et al. 2018, Jourgholami et al. 2019, Picchio et al. 2019a, 2019b).

Soil recovery is defined as the ability of impacted soil parameters (i.e., physical, chemical, biological) to restore or return to any former state or condition in response to the effects of disturbance (Rab 2004). Previous studies have proved that the nat- 
ural recovery of soil properties from compaction following machine traffic is a longterm process, which can take from a few years to several decades (Goutal et al. 2013, Klaes et al. 2016, Picchio et al. 2019b). Nevertheless, the biotic and abiotic mechanisms such as interactions between roots and soil, clay particle expansion and retraction, water freezing and thawing, and macro- and micro-fauna activities can accelerate the recovery processes of soil properties under natural conditions (Ebeling et al. 2016). In the case of the Hyrcanian forests, Jourgholami et al. (2018) reported that the physical, chemical, and biological properties of forest soil compacted after mechanized logging operations were significantly restored by the application of mulch with high-quality litter (i.e., hornbeam and maple), in comparison to the untreated trails. However, a full recovery of soil properties did not occur within a 5-year period after forest harvesting operations. Soil compaction has a major impact on the growth and/or mortality rates of forest tree seedlings (Picchio et al. 2019a). For example, Picchio et al. (2019a) monitored and evaluated soil physical properties (i.e., bulk density, penetration resistance, and total porosity) and their effects on maple and beech seedlings on 10-year-old skid trails in the Iranian Caspian forests. Their results indicated soil bulk density increased by $12.6 \%$ on the skid trails (between two skidder tires on each skid trail) and $36.1 \%$ on tire tracks, compared to non-skid trails (1.19 g $\mathrm{cm}^{-3}$ ), penetration resistance increased by $68 \%$ on skid trails and $220 \%$ on tire tracks, compared to non-skid trails ( $0.25 \mathrm{MPa})$, total porosity decreased by $12.8 \%$ on skid trails and $30.9 \%$ on tire tracks, compared to non-skid trails (54\%).

In recent years, several approaches focused on the soil restoration after harvesting through a sustainable forest management (SFM) and the application of sustainable forest operations (SFO). Starting from the observation of a natural phenomenon called the "treefall gap" and its influence on the forest soil, it was possible to de velop a specific experimental design.

A treefall gap is a canopy opening of forest stand related to the fall or death of one or more trees at the dominant or co-dominant levels (Scharenbroch \& Bockheim 2011, Muscolo et al. 2014, Yang et al. 2017, Liu et al. 2018). Canopy gaps play a key role in ecological succession processes of oldgrowth forests by maintaining structural diversity and canopy dynamics (He et al. 2015), increasing light thus favoring soil and plant richness and diversity (Scharenbroch \& Bockheim 2008, Ni et al. 2015), modifying temperature and soil moisture (Latif \& Blackburn 2010), altering the nutrient cycling (Muscolo et al. 2007), and inducing a suitable microclimate (Latif \& Blackburn 2010).

Canopy gaps regulate soil temperature and snow cover which influence microbial biomass in the organic layer (He et al. 2015,
Liu et al. 2018). Previous studies reported that large-size gaps caused a decrease in organic matter cycling and in nutrient release due to the lower amount of litter input and higher decomposition rates (Muscolo et al. 2007). In the hardwood forests in the Upper Michigan Peninsula (USA), there was a significant decrease in soil microbial and endomycorrhizal biomass, as well as soil respiration as gap size increased (Schliemann \& Bockheim 2014). In Pinus tabulaeformis stands in northern China, the highest concentrations of soil microbial communities and enzymatic activity were observed in the canopy gaps (Yang et al. 2017). Accordingly, Scharenbroch \& Bockheim (2011) stated that largesize gaps need more time than small-size ones to recover from perturbation conditions. Also, Sefidi et al. (2011) found that the higher values were related to the natural canopy gaps with an area less than 200 $\mathrm{m}^{2}$. Moreover, fallen beech trees were the cause of gaps in the most cases in the Hyrcanian beech forests.

A comprehensive review by Coates \& Burton (1997) focused on literature concerning gap dynamics and gap size or position as predictive variables for silvicultural success or maintenance of ecosystem function. However, no data were provided concerning the potential effects of logging operations. According to Sefidi et al. (2011), close-to-nature forest management based on mimicking natural canopy gaps is a wellknown practice in old-growth Hyrcanian beech forests. However, snowfall and wind damage were known as main ecological disturbances, which can create a gap in the canopy cover. This open area forms an appropriate environment for developing the next generation of tree species, which can affect the dynamics and biodiversity of forest stands (Gardiner et al. 2016).

As reported by several authors (Ritter 2005, Muscolo et al. 2007, Özcan \& Gökbulak 2015), the harvesting practices in the gaps may cause further disturbance to soil. However, there is a lack of knowledge on the effect of gaps on soil characteristics, in particular, referring to disturbed soil and related recovery capacities.

Concerning ecological processes of above- and below-ground forest ecosystems, there is hardly any information available in the literature about the effects of natural treefall gaps (as well as those of man-made gaps) on the recovery of compacted soil properties and biological activity. In this study, we hypothesized that small-size natural treefall gaps can accelerate the restoration of compacted soil by enhancing the biological and microbial activity in the topsoil. The study was conducted at the end of a five-year period after logging operations. The objectives of this study were: (i) to elucidate the effects of two different sizes of canopy gaps on the recovery of compacted soil physical and chemical properties five years after ground-based skidding operations; and (ii) to determine the responses of soil microbial respiration and biological activity to canopy gaps, as compared to an undisturbed area.

\section{Materials and methods}

\section{Site description}

The study areas were established in the compartment no. 310 of the Gorazbon District in the Kheyrud Forest of the greater Hyrcanian forest (northern Iran), at an altitude of 1070-1180 m a.s.l. with a southern aspect (Fig. 1a). The eco-region of the Hyrcanian mixed forests known as old-growth forests are ecosystems characterized by old trees and related structural attributes including large diameter trees, a large proportion of woody debris and dead woody material, multi-layered canopies and canopy gaps, multiple species composition, floristic biodiversity, important natural features, and very high ecological values. Until 2013, it had no history of any previous harvest entries anywhere near the sampling area. The climate of the study area is humid cold (Dsa, based on Köppen-Geiger Climate Classification) with a one-month dry period occurring in July (Fig. 2). The mean annual rainfall is $1308 \mathrm{~mm}$ with the highest monthly rainfall occurring in October and the lowest in July. The average annual temperature is $8.5{ }^{\circ} \mathrm{C}$, with July being the hottest month and January the coldest one. The soil in the study area is a deep brown soil (Alfisol, according to the USDA Soil Taxonomy; Calcic Cambisols according to World Reference Base), with silt-loam texture derived from limestone, belonging to the upper Jurassic and lower Cretaceous periods. The dominant tree species in the study area is Oriental beech (Fagus orientalis Lipsky), which is accompanied by other species including hornbeam (Carpinus betulus L.), chestnut-leaved oak (Quercus castaneifolia C. A. Mey), and Caucasian alder (Alnus subcordata C. A. Mey). Tree marking was done in September 2012 and trees were felled by chainsaw in March 2013. A combination of group selection and single-tree selection was applied as the prevalent silvicultural treatment. The average growing stock, total number and volume of removed trees in compartment no. 310 were $477.2 \mathrm{~m}^{3} \mathrm{ha}^{-1}, 148$ trees, and $813.7 \mathrm{~m}^{3}(31.8$ $\mathrm{m}^{3}$ ha $\left.^{-1}\right)$, respectively. A Timberjack ${ }^{\circledast} 450 \mathrm{C}$ four-wheeled skidder with an empty weight of $10.3 \mathrm{t}$ and tires inflated to 220 $\mathrm{kPa}$ was used to extract the logs in June 2013 (Fig. 1b); the average load volume was 3.4 cubic meters, and operating trails had a width of $3.5 \mathrm{~m}$. All the skid trails in the different gaps had the same amount of traffic and number of passes.

\section{Experimental design and soil sampling}

The skid trails were tracked using GPS in 2013 in order to know the exact layout of the trails. Five years after skidding operations, three treatments were randomly selected with four replications in the four 
skid trails as well as in the undisturbed area to assess the recovery process of soil properties for this study (Fig. 1a). The treatments included were as follows: natural canopy gap with an area of $200 \mathrm{~m}^{2}$ (NCG); clear-cut with an area of $1600 \mathrm{~m}^{2}$ (CC); disturbed trails under a dense canopy (DDC); and the undisturbed area (UND). The natural gaps of the NCG treatment were formed in 2013 due to uprooting (tree throw) and stem breakage following wet snowfall and wind damage (Gardiner et al. 2016). Hence, all of the four treatments were formed in the same year (2013). These natural canopy gaps were caused by single dead trees and the gap makers were beech trees. To avoid side effects, the plots were located only in areas dominated by beech trees. Clear-cut (CC) plots were contiguously closed canopy forest before being clear-cut. Every small canopy gap (NCG) was perfectly located on the skid-trails center and completely covered the $20 \times 4 \mathrm{~m}$ sample section of each skid-trail. The characteristics of each treatment are given in Tab. 1. One replication of each treatment was placed on or near each of the four skid trails and sampling plots were established at an equal distance from landings (50-100 $\mathrm{m})$. Different segments of the trails had the same slope gradients of $15-20 \%$, and were exposed to a high level of machine traffic (ranging 15-20 machine cycles), near the maximum damage level as reported by Cambi et al. (2015), so as to eliminate the effects of machine traffic intensity and skid trail slope on soil compaction level. The soil sampling plots were oriented and positioned in the skid trail on or near the center of the gaps. In each replication, three plots were randomly established. Then a plot was randomly selected to sample the soil physical, chemical, biological and biochemical properties in June 2018. The sampling plot with a length of $20 \mathrm{~m}$ and a width of 4 $m$ was established on the skid trail at each treatment. In each selected sample plot, five transects were established which were perpendicular to the longitudinal axis of the trail at an interval of $4 \mathrm{~m}$, and three of those transects were randomly selected for soil sampling. Soil samples were taken in the undisturbed area (UND) with four replicates adjacent to the skid trails at a distance of $30 \mathrm{~m}$ from the trails, to verify the soil properties compared to other treatments. In each treatment, four sample plots were measured, thus providing 36 soil samples. In total, 120 soil samples were collected and analyzed in June 2018 , i.e., 4 skid trails $\times 3$ treatments (NCG, CC, and DDC $) \times 3$ randomly selected transects across the sampling plot (out of 5 ) $\times 3$ soil samples per transect +12 soil samples in the UND area.

Some soil characteristics were selected to test the soil disturbance and recovery, according to Picchio et al. (2012) who found bulk density, total porosity, aggregate stability, and penetration resistance to be good indicators of physical soil quality. Soil
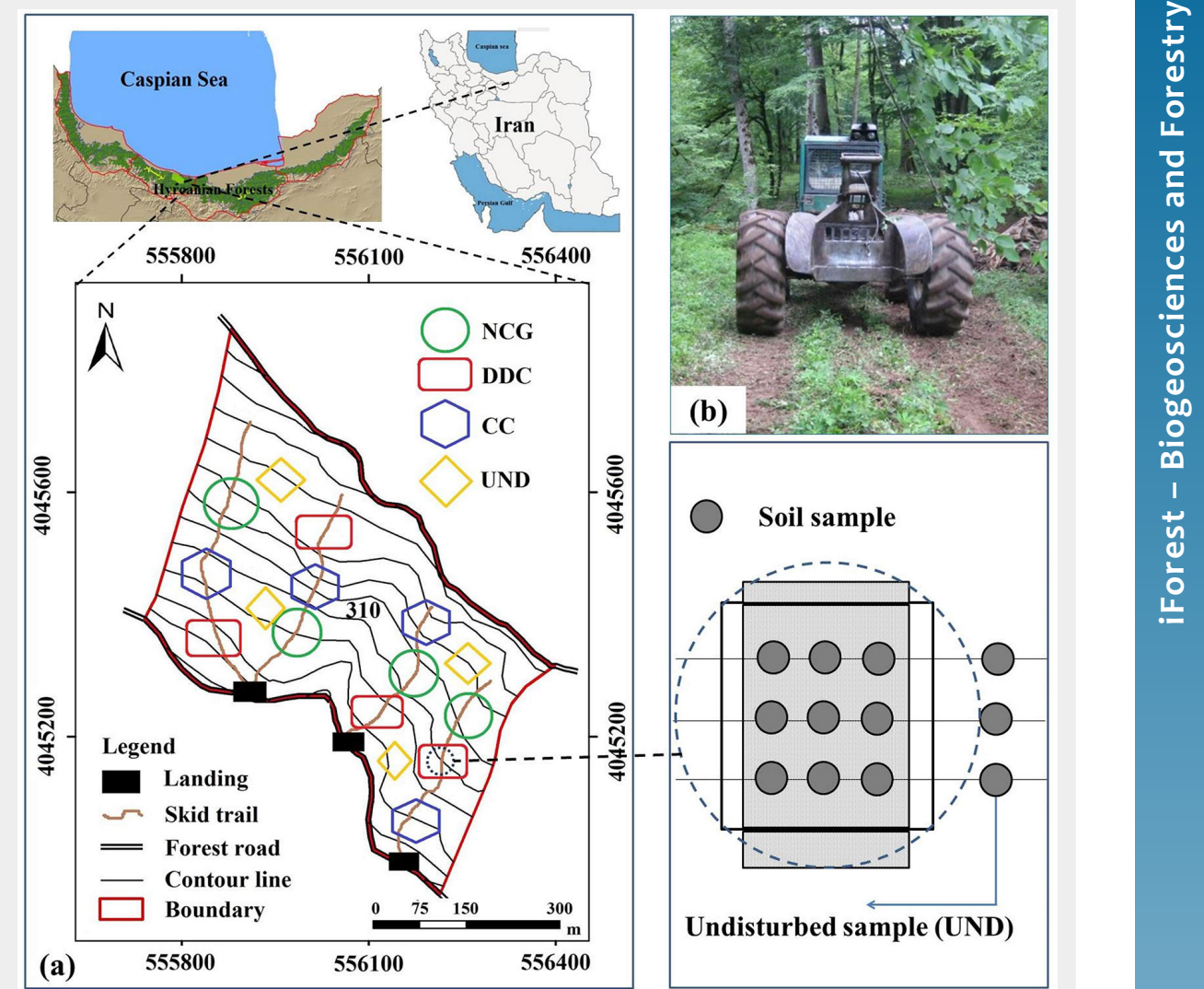

Fig. 1 - (a) The study area in Kheyrud forests (compartment no. 310 of Gorazbon Dis trict) in the Hyrcanian forests (northern Iran) and the the experimental design in relation to the skid trails; the treatments are as follows: natural canopy gap with area of $200 \mathrm{~m}^{2}$ (NCG); clear-cut with area of $1600 \mathrm{~m}^{2}$ (CC); disturbed trails under dense canopy (DDC); and the undisturbed area (UND); (b) the Timberjack ${ }^{\circledR} 450 \mathrm{C}$ skidder travelling unloaded on the skid trail.

samples were collected from the surface soil at less than a depth of $10 \mathrm{~cm}$ by using a steel cylinder with a height of $40 \mathrm{~mm}$ and a diameter of $56 \mathrm{~mm}$, placed in plastic bags, and shipped to the lab. Soil samples were weighed in a fresh state and then again after oven-drying at $105{ }^{\circ} \mathrm{C}$, upon reaching constant mass for measuring water content and soil bulk density. The following soil physical properties were determined: soil particle size distribution for particles smaller than $0.075 \mathrm{~mm}$ by applying the hydrometer method (Gee \& Bauder 1986), soil particle size distribution for larger particles by screening through a series of sieves, macroporosity using the water des- orption method (Danielson \& Southerland 1986), soil penetration resistance (PR) by using an analog hand-held soil penetrome-

Tab. 1 - The treatments characteristics (mean \pm standard deviation) in the study area.

\begin{tabular}{ccc}
\hline Treatment & $\begin{array}{l}\text { Canopy } \\
\text { cover }(\%)\end{array}$ & $\begin{array}{l}\text { Gap area } \\
\left(\mathrm{m}^{2}\right)\end{array}$ \\
\hline UND & $85 \pm 9$ & 0 \\
\hline NCG & 0 & $200 \pm 38$ \\
\hline DDC & $81 \pm 7$ & 0 \\
\hline CC & 0 & $1600 \pm 252$ \\
\hline
\end{tabular}

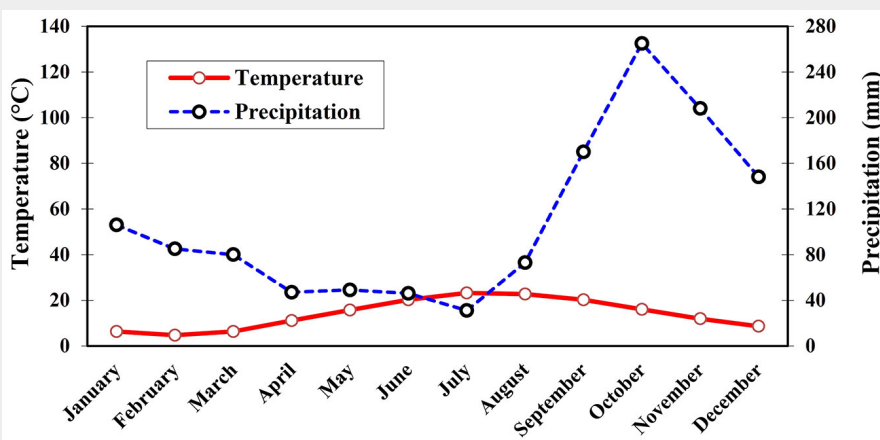

Fig. 2 - Mean monthly temperature and precipitation in the study area. 
ter (model 06.01.SA, Eijkelkamp, Giesbeek, Netherlands) with a $60^{\circ}$ cone and a maximum measuring depth of $1 \mathrm{~m}$, as well as ag gregate stability by applying the wet sieving procedure (Kemper \& Rosenau 1986).

Prior to the soil sampling for determine soil chemical properties the litter layer was removed from an area of $25 \times 25 \mathrm{~cm}$ within a depth of $10 \mathrm{~cm}$. The collected soil samples were sealed in plastic bags, labeled, transported to the laboratory, air-dried, and then screened through a 2-mm sieve. The following soil chemical properties were determined: soil $\mathrm{pH}$ in a solution with a ratio of soil to water of 1:2.5 using the Orion lonalyzer ${ }^{\circledast}$ (model 901, Orion Corp., Espoo, Finland) $\mathrm{pH}$ meter, soil organic $\mathrm{C}$ by applying the Walkley-Black technique (Walkley \& Black 1934), total $\mathrm{N}$ by using the Kjeldahl method (Kooch et al. 2014), available phosphorous $(P)$ using the Olsen method with a spectrophotometer, and available potassium (K), calcium (Ca) and magnesium $(\mathrm{Mg})$ by ammonium acetate extraction at $\mathrm{pH} 9$ and applying an atomic absorption spectrophotometer (Kooch et al. 2014). The number and density of earthworms were determined by manual sampling on the surface soil within an area of $25 \times 25 \mathrm{~cm}$ and a depth of $10 \mathrm{~cm}$ after removing the litter layer. The three main ecological types of earthworms, i.e., epigeic, anecic and endogeic earthworms, were identified based on the identification key of Edwards \& Bohlen (1996). To determine earthworm dry mass, the earthworms were washed, weighed, and oven dried at $60^{\circ} \mathrm{C}$ for $24 \mathrm{~h}$ (Jourgholami et al. 2018). Soil microbial respiration was determined by measuring the $\mathrm{CO}_{2}$ evolved in a 3-day incubation experiment at $25{ }^{\circ} \mathrm{C}$ (Kooch et al. 2014). Fine roots with a diameter of less than $2 \mathrm{~mm}$ were extracted from each sample and dried at $70{ }^{\circ} \mathrm{C}$ to a constant mass for measuring fine root biomass (Jourgholami et al. 2019).

\section{Statistical analyses}

A factorial experiment with a complete block design was assigned to the treatments (NCG, CC, DDC, and UND area). The Kolmogorov-Smirnov test $(\alpha=0.05)$ was used to check the soil properties data for normality. The Levene's test ( $\alpha=0.05)$ was applied to check the homogeneity of variance among treatments. One-way analysis of variance (ANOVA) was used to relate soil physical, chemical, biological, and biochemical properties recovery in response to treatment. Tukey post-hoc test was used to check the statistically significant differences of the mean values of the treatment group with a $95 \%$ confidence level. All statistical tests were performed using the software package SPSS ${ }^{\circledR}$ v. 17.0 (IBM, Armonk, NY, USA). Principal component analysis (PCA) was performed to explore the relationship among soil properties in differ- ent treatments using the $\mathrm{XLSTAT}^{\circledR} 2016$ software (Addinsoft, Paris, France).

\section{Results}

\section{Soil physical properties}

All soil physical properties were significantly different $(P<0.05)$ among treatments, except for silt content. The highest soil bulk density, penetration resistance, sand content, and the lowest macroporosity were detected for the $\mathrm{CC}$ treatment followed by DDC and NCG (Tab. 2). The highest soil moisture $(42.91 \%)$ was found in the UND area followed by DDC > NCG > CC treatments. Aggregate stability and clay content were highest in the UND area followed by NCG $\approx D D C>C C$. Except for soil moisture (Tukey test, $P>0.05$ ), the highest recovery values of all soil physical properties were found in the NCG treatment, while the lowest recovery values were detected for the $\mathrm{CC}$ treatment. Nevertheless, the soil physical values did not fully recover among the different types of treatment (i.e., NCG, DDC, and CC) even after five years, and resulted to be even higher than the values of the undisturbed area (UND Tab. 2).

\section{Soil chemical properties}

All soil chemical properties were significantly influenced by treatment (Tab. 2). Remarkably, soil $\mathrm{pH}$ were higher in the $\mathrm{CC}$ fol-

Tab. 2 - Means ( \pm standard deviation; $n=120$ ) of soil physical, chemical, biochemical and biological properties in the four treatments. The treatments are included as follow: natural canopy gap with area of $200 \mathrm{~m}^{2}$ (NCG), clear-cut with area of $1600 \mathrm{~m}^{2}$ (CC), disturbed trails under dense canopy (DDC), and the undisturbed area (UND). Results of the ANOVAs ( $F$ test and $P$ value) are given. Different letters within a row indicate significant differences $(P<0.05)$ between treatment means after Tukey test.

\begin{tabular}{|c|c|c|c|c|c|c|c|}
\hline $\begin{array}{l}\text { Soil } \\
\text { properties }\end{array}$ & Variable & UND & NCG & DDC & CC & $F$ test & $P$ value \\
\hline \multirow{8}{*}{$\begin{array}{l}\text { Physical } \\
\text { properties }\end{array}$} & Bulk density $\left(\mathrm{g} \mathrm{cm}^{-3}\right)$ & $0.93 \pm 0.06^{d}$ & $1.07 \pm 0.10^{c}$ & $1.23 \pm 0.13^{b}$ & $1.35 \pm 0.11^{\mathrm{a}}$ & 62.08 & $<0.001$ \\
\hline & Macroporosity (\%) & $41.27 \pm 1.38^{d}$ & $36.28 \pm 2.35^{c}$ & $27.82 \pm 2.66^{b}$ & $23.47 \pm 2.15^{\mathrm{a}}$ & 287.28 & $<0.001$ \\
\hline & Penetration resistance $(\mathrm{MPa})$ & $0.92 \pm 0.17^{d}$ & $1.11 \pm 0.18^{c}$ & $1.31 \pm 0.18^{b}$ & $1.55 \pm 0.22^{\mathrm{a}}$ & 46.88 & $<0.001$ \\
\hline & Soil moisture (\%) & $42.91 \pm 6.0^{\mathrm{a}}$ & $32.64 \pm 6.34^{c}$ & $37.64 \pm 5.65^{b}$ & $26.46 \pm 4.0^{d}$ & 38.72 & $<0.001$ \\
\hline & Aggregate stability (\%) & $53.86 \pm 6.68^{a}$ & $42.27 \pm 6.46^{b}$ & $38.71 \pm 7.41^{\mathrm{b}}$ & $29.41 \pm 6.25^{c}$ & 46.61 & $<0.001$ \\
\hline & Sand (\%) & $12.38 \pm 1.31^{\mathrm{c}}$ & $14.41 \pm 2.88^{b}$ & $13.26 \pm 1.88^{b}$ & $17.17 \pm 1.77^{\mathrm{a}}$ & 25.80 & $<0.001$ \\
\hline & Silt (\%) & $56.23 \pm 2.11^{\mathrm{a}}$ & $55.46 \pm 1.13^{a}$ & $56.28 \pm 1.98^{a}$ & $55.71 \pm 1.62^{\mathrm{a}}$ & 1.75 & 0.16 \\
\hline & Clay (\%) & $31.39 \pm 3.4^{\mathrm{a}}$ & $30.13 \pm 2.1^{b}$ & $30.46 \pm 06^{b}$ & $27.12 \pm 0.7^{c}$ & 43.95 & $<0.001$ \\
\hline \multirow{8}{*}{$\begin{array}{l}\text { Chemical } \\
\text { properties }\end{array}$} & $\mathrm{pH}\left(1: 2.5 \mathrm{H}_{2} \mathrm{O}\right)$ & $5.33 \pm 0.23^{c}$ & $5.51 \pm 0.33^{c}$ & $6.01 \pm 0.4^{b}$ & $6.83 \pm 0.42^{a}$ & 93.66 & $<0.001$ \\
\hline & $E C\left(d_{s} m^{-1}\right)$ & $0.19 \pm 0.02^{c}$ & $0.22 \pm 0.05^{c}$ & $0.29 \pm 0.05^{b}$ & $0.38 \pm 0.06^{a}$ & 76.87 & $<0.001$ \\
\hline & C (\%) & $4.11 \pm 0.43^{\mathrm{a}}$ & $3.02 \pm 0.41^{b}$ & $2.93 \pm 0.1^{b}$ & $1.86 \pm 0.38^{c}$ & 163.81 & $<0.001$ \\
\hline & $\mathrm{N}(\%)$ & $0.53 \pm 0.08^{a}$ & $0.29 \pm 0.04^{b}$ & $0.21 \pm 0.04^{c}$ & $0.11 \pm 0.04^{d}$ & 303.82 & $<0.001$ \\
\hline & Available $\mathrm{P}\left(\mathrm{mg} \mathrm{kg}^{-1}\right)$ & $26.47 \pm 3.88^{a}$ & $24.91 \pm 3.08^{a}$ & $21.62 \pm 4.27^{b}$ & $14.39 \pm 3.58^{c}$ & 60.90 & $<0.001$ \\
\hline & Available $\mathrm{K}\left(\mathrm{mg} \mathrm{kg}^{-1}\right)$ & $231.12 \pm 15.46^{a}$ & $201.47 \pm 24.6^{b}$ & $196.31 \pm 22.11^{\mathrm{b}}$ & $141.75 \pm 21.89^{c}$ & 71.88 & $<0.001$ \\
\hline & Available Ca (mg kg-1) & $177.41 \pm 13.62^{\mathrm{a}}$ & $168.11 \pm 26.93^{a}$ & $165.93 \pm 21.91^{\mathrm{a}}$ & $108.37 \pm 18.48^{b}$ & 63.55 & $<0.001$ \\
\hline & Available $\mathrm{Mg}\left(\mathrm{mg} \mathrm{kg}^{-1}\right)$ & $47.16 \pm 3.43^{a}$ & $41.89 \pm 3.6^{b}$ & $39.76 \pm 4.29 \mathrm{bc}$ & $38.43 \pm 4.49^{c}$ & 15.38 & $<0.001$ \\
\hline \multirow{4}{*}{$\begin{array}{l}\text { Biochemical } \\
\text { and } \\
\text { biological } \\
\text { properties }\end{array}$} & Earthworm density $\left(\mathrm{n} \mathrm{m}^{-2}\right)$ & $1.96 \pm 0.41^{\mathrm{a}}$ & $1.14 \pm 0.16^{b}$ & $0.63 \pm 0.11^{c}$ & $0.12 \pm 0.04^{d}$ & 444.73 & $<0.001$ \\
\hline & Earthworm dry mass ( $\mathrm{mg} \mathrm{m}^{-2}$ ) & $28.34 \pm 4.44^{\mathrm{a}}$ & $15.65 \pm 2.02^{b}$ & $8.17 \pm 1.4^{\mathrm{c}}$ & $2.17 \pm 1.03^{d}$ & 619.26 & $<0.001$ \\
\hline & $\begin{array}{l}\text { Soil microbial respiration } \\
\left(\mathrm{mg} \mathrm{CO}_{2}-\mathrm{C}_{\text {soil }}{ }^{-1} \text { day }^{-1}\right)\end{array}$ & $0.49 \pm 0.08^{a}$ & $0.37 \pm 0.06^{b}$ & $0.33 \pm 0.05^{b}$ & $0.28 \pm 0.05^{c}$ & 43.26 & $<0.001$ \\
\hline & Fine root biomass $\left(\mathrm{g} \mathrm{m}^{-2}\right)$ & $92.27 \pm 7.66^{a}$ & $74.63 \pm 15.1^{b}$ & $82.73 \pm 18.84^{a b}$ & $34.81 \pm 8.34^{c}$ & 92.16 & $<0.001$ \\
\hline
\end{tabular}


lowed by DDC > NCG $\approx$ DDC area (Tab. 2). The highest contents of soil organic $C$ were measured in the UND area (4.11\%) followed by $\mathrm{NCG} \approx \mathrm{DDC}>\mathrm{CC}$ treatments. The $\mathrm{N}$ content was highest for the UND area (0.53\%) followed by NCG > DDC > CC treatments. The values of available $\mathrm{P}\left(26.47 \mathrm{mg} \mathrm{kg}^{-1}\right), \mathrm{K}$ (231.12 $\left.\mathrm{mg} \mathrm{kg}^{-1}\right), \mathrm{Ca}\left(177.41 \mathrm{mg} \mathrm{kg}^{-1}\right)$, and $\mathrm{Mg}$ (47.16 $\mathrm{mg} \mathrm{kg}^{-1}$ ) were highest for the UND area (Tab. 2). The highest recovery values of chemical properties were observed for the NCG followed by DDC and CC treatments. However, all the measured values continued to be lower than in the UND area 5 years after traffic activity (Tab. 2).

\section{Soil biochemical and biological properties}

The earthworm density and dry mass, soil microbial respiration, and fine root biomass were significantly different among treatments (Tab. 2). Significantly higher values of earthworm density and dry mass, and soil microbial respiration were found in the UND area followed by NCG > DDC > CC treatments. Fine root biomass was significantly higher in the UND area $\left(92.27 \mathrm{~g} \mathrm{~m}^{-2}\right)$ followed by DDC > NCG > CC treatments (Tab. 2). Five years after machine traffic on the skid trails, the recovery values of earthworm density and dry mass, and soil microbial respiration were higher in the NCG followed by DDC and CC treatments, all being lower than the values of the UND area, but the recovery values of fine root biomass were highest in the DDC followed by NCG and CC treatments (Tab. 2). In all of the treatments as well as the UND area, density and dry mass of epigeic earthworms were significantly higher than the corresponding values for anecic and endogeic earthworms (Fig. 3a, Fig. 3b).

\section{PCA of the treatments and soil} properties

The PCA analysis revealed that the first and second principal components explained $87.97 \%$ and $8.1 \%$ of the total variance, respectively (Fig. 4). On the positive side of the first principal component, the UND area and the NCG treatment were positively correlated with a favorable soil quality, such as the high values of physical properties which are macroporosity, aggregate stability, silt and clay content, soil moisture, high values of chemical properties such as organic $C$, total $\mathrm{N}$, available $\mathrm{P}$, $\mathrm{K}, \mathrm{Ca}$, and $\mathrm{Mg}$, and high values of biological properties (earthworm density, earthworm dry mass, soil microbial respiration, and fine root density) of soils. The negative side of the first principal component represents an unfavorable soil quality, corresponding to high values of the physical properties bulk density, penetration resistance, sand content and high values of the chemical properties soil $\mathrm{pH}$, and EC. This correlates with the DDC and CC treatments (Fig. 4).
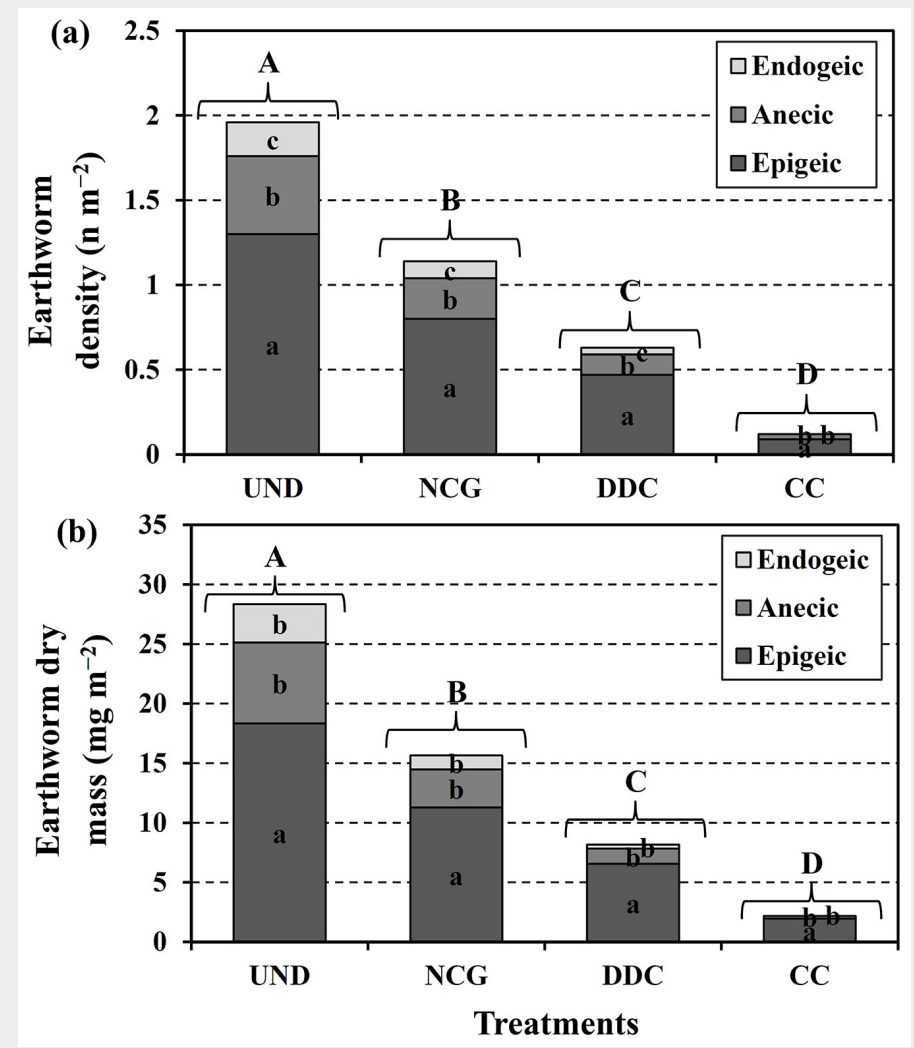

Fig. 3 - Mean values of epigeic, anecic and endogeic density (a) and dry mass (b) under four treatments. Lowercase letters within the bars and capital letters above bars indicate significant differences $(P<0.01)$ based on Tukey tests, among earthworm categories and different treatments, respectively.

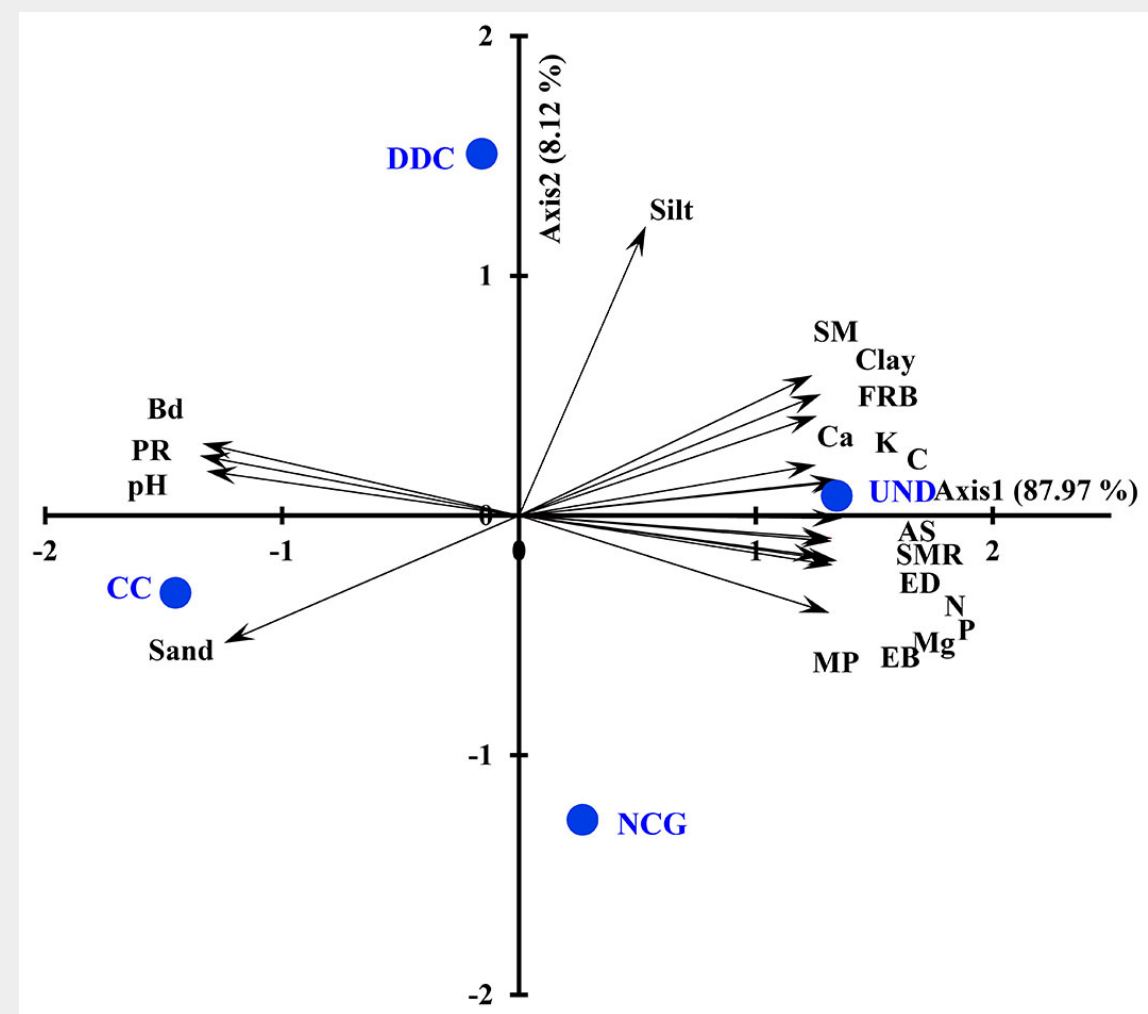

Fig. 4 - PCA biplot showing the principle component scores of the different treat ments (NCG: natural canopy gap with area of $200 \mathrm{~m}^{2}$; CC: clear-cut with area of 1600 $\mathrm{m}^{2}$; DDC: disturbed trails under dense canopy; UND: the undisturbed area), and the loadings of the physical variables (BD: bulk density; MP: macroporosity; PR: penetration resistance; MC: moisture content; AS: aggregate stability, sand, silt, clay), chemical variables (pH; EC; C: organic C; N: nitrogen content; P: available phosphorous; K: available potassium; Ca: available calcium; Mg: available magnesium), and biological variables (ED: earthworm density; EB: earthworm dry mass; SMR: soil microbial respiration; FRB: fine root biomass). 


\section{Discussion}

\section{Soil physical properties}

The recovery values of soil physical prop erties (i.e., bulk density, macroporosity, penetration resistance, and aggregate stability) were highest in NCG compared to the DDC and CC treatments. However, soil physical properties under the NCG, DDC, and $C C$ treatments did not fully recover within 5 years after gap formation compared to the UND area. The results of the current study revealed that soil physiochemical and biological properties were restored after creating small-size gaps, following previous literature findings (Muscolo et al. 2014, Schliemann \& Bockheim 2014, He et al. 2015). In line with the current study, He et al. (2015) found that soil physical properties are significantly correlated with canopy gap sizes. Several studies have shown significant correlations between gap size and some factors such as soil moisture content and solar radiation (Sariyildiz 2008, Muscolo et al. 2014). The received levels of solar radiation logarithmically increased as the gap size increased (Canham et al. 1990). These results are consistent with He et al. (2015) who reported that soil pore space structure in small gaps shows more enhancement than in the medium and large gaps.

\section{Soil chemical properties}

The recovery values of soil chemical properties were highest in the NCG treatment as compared to the DDC and CC treatments, but they were still lower than the values of the UND area even 5 years after machine traffic. The larger gaps can allow for the soil surface to receive more rainfall, thus increasing runoff (Jourgholami et al. 2018) while causing an increase in the loss of nutrients during the leaching process, which leads to a deficit of the inorganic nitrogen levels in soils (Ritter 2005, Muscolo et al. 2007, Sariyildiz 2008, He et al. 2015). Meanwhile, if the surface of the canopy has large-size openness, the concentration of nutrients due to leaching in the upper layer of soil will show a significant deficit compared to the NCG, as already reported by Schliemann \& Bockheim (2014). Accordingly, the significant decrease in available soil nutrients in the $\mathrm{CC}$ treatment can be attributed to the large opening area in the canopy cover. Litter decomposition rates were higher in small-size gaps than in largesize gaps due to the higher microbial activity, which is significantly impacted by soil moisture and the higher inputs of organic matter from neighboring trees in gaps, which is in accordance with the results of Ritter (2005), Sariyildiz (2008), and Muscolo et al. (2014). Consistent with our findings, several studies indicated that the alterations of the microclimate and microbial populations, as well as the reduction of nutrient uptake, are the most important variables causing the high levels of biogeochemical cycling in small-size gaps (Sariy- ildiz 2008, Schliemann \& Bockheim 2014, He et al. 2015, Yang et al. 2017). Additionally, Schliemann \& Bockheim (2014) reported a decrease in $\mathrm{NH}_{4}{ }^{+}$content by increasing gap size due to the lower canopy interception in larger gaps, which resulted in a decrease in the interception of $\mathrm{N}$ by canopy cover.

Similar to our findings, Scharenbroch \& Bockheim (2008) demonstrated that the forest floor C and coarse particulate organic matter in soil were higher in the closed canopy than in the treefall gaps. Due to the higher decomposition rate of organic matter, treefall gaps can act as a reductant for organic $C$ in the old-growth beech forests (Scharenbroch \& Bockheim 2008). After gap formation and subsequent soil disturbance caused by logging operations, the biomass of dead trees is transferred to organic matter and then, the soil organic matter is strongly decomposed by soil microbial activities according to Scharenbroch \& Bockheim (2008). Additionally, the results of this study can be explained based on the "leaky bucket" model (Field \& Kaduk 2004) and therefore newly formed natural canopy gaps are a source of C (He et al. 2015), which enhanced the decomposition rate of organic matter over time. Previous studies reported that the increase of soil $\mathrm{pH}$ enhances the decomposition rate of litter and nutrient mineralization, which in turn results in an alteration of the soil organisms from fungi to bacteria (Bauhus et al. 2004, Lin et al. 2015). Meanwhile, the decomposition of gap makers in the NCG following microbial activity enhances the organic matter content, which results in an increase of soil total $\mathrm{N}$ ( $\mathrm{He}$ et al. 2015). Previous studies found that the favorable conditions of soil temperature and moisture enhanced invertebrate and microbial activities, which lead to a higher degree of humification in gaps than that of the closed canopy (Sierra \& Motisi 2012, Ni et al. 2015).

Our results revealed that the total $\mathrm{N}$ and available nutrients were significantly higher in the NCG than in the DDC and CC treatments. Similarly, Xu et al. (2016) found that soil $\mathrm{N}$ and $\mathrm{P}$ were higher in small gaps and under closed canopy than in large gaps. Accordingly, the higher decomposition rate of the litter and the greater leaching of nutrients in large size gaps led to decreased enzyme activity, which resulted in a decrease in soil fertility (Xu et al. 2016). Similarly, Hu et al. (2016) recommended a gap of 100 to $200 \mathrm{~m}^{2}$ for $\mathrm{P}$ restoration in forest soil. Our results also revealed that soil $\mathrm{C}$ in the NCG was lower than in the DDC and CC treatments. Similar to our findings, Thiel (2008) demonstrated that the litter $C$ was significantly lower in gaps than in the stands with a closed canopy. Consistently, with our study, previous investigations suggested that organic matter decomposition rates and nutrient availability were regulated by soil microbial populations and enzyme activity, which in turn were enhanced by canopy gaps (He et al. 2015, Yang et al. 2017). By increasing the gap size, the microbial biomass decreased, which can have a significant impact on nutrient cycling (Schliemann \& Bockheim 2014).

\section{Soil biochemical and biological properties}

Generally, the recovery values of earthworm density and dry biomass were higher in the NCG. However, these values were still lower than the values of the UND area. The accumulation of earthworms under the UND area and small size gaps such as NCG can be attributed to high soil moisture content (Latif \& Blackburn 2010, Yang et al. 2017). The most favorable conditions, particularly the higher water content in the closed canopy and small-size gap, are the main drivers for the higher accumulation of earthworms (Prescott 2002, Xu et al. 2016). The accumulation of earthworms showed a positive relationship with the clay content of the soil in both DDC and NCG treatments, which in turn increased the soil moisture content. A similar trend was observed in the effects of canopy gap size on different types of earthworms. On all skid trails, the frequency of epigeic was greater than the anecic and endogeic. These results indicate that epigeic was more effective than the anecic and endogeic in the soil recovery process. Epigeic earthworms live in the soil surface layer and play a crucial role in the formation of humus (Kooch et al. 2014). Endogeic was not observed in the CC treatment, giving evidence to its higher level of sensitivity to canopy opening as compared to the anecic and epigeic. Our results showed that the soil microbial respiration was higher in NCG than in CC. The recovery level of soil microbial properties were higher in light compacted soils than in severe compacted ones (Hartmann et al. 2014). In line with the current study, Scharenbroch \& Bockheim (2008) found that soil microbial biomass was higher in the small gaps as compared to the closed forests, since the microclimate and substrate conditions in small gaps were optimal for the microbial community. The higher recovery value of soil microbial respiration in NCG than in other treatments contributed to the greater microbial biomass, bacteria as well as fungi, which in turn led to a higher decomposition rate of organic matter and mineralization (Yang et al. 2017). Further, our study is in line with the results from Muscolo et al. (2007), Xu et al. (2016), and Yang et al. (2017), which confirmed that litter inputs with high labile $\mathrm{C}$ and $\mathrm{N}$ were higher in the large gaps than in the small gaps, as well as the higher leaching, which in turn led to decrease organic matter. Additionally, the lower soil moisture in the large gaps creates unfavorable surrounding conditions, which results in a deceleration of enzyme and microbial activities (Scharenbroch \& Bockheim 2008, Xu et al. 2016).

The greater recovery value of fine root 
biomass in the DDC and NCG treatments compared to the $\mathrm{CC}$ treatment can be attributed to the favorable environment due to the proper conditions of soil physiochemical properties in small size gaps. Also, the lowest recovery amounts of earthworm density and dry biomass in the CC treatment can be attributed to a larger gap size and higher soil bulk density, which led to lower soil moisture, which in turn resulted in an increase of the sand particles and adverse ecological conditions for earthworms. Similarly, some studies reported that fine root biomass and rates of soil respiration are lower in the canopy gaps than under the closed canopy (Schliemann \& Bockheim 2014, Lin et al. 2015). These results are consistent with the findings by $\mathrm{He}$ et al. (2015), stating that the microbial induced decomposition and mineralization rates were higher in the canopy gaps than in the closed canopy due to favorable conditions for microbial activities in the gaps.

One important concern to interpret our results is the differences in soil temperature, solar radiation, and snow cover among the treatments. According to the above mentioned literature, soil temperature can play a crucial role in the recovery processes of soil properties after soil compaction. However, soil moisture was measured in this study, hence the decrease/increase of soil moisture in the soil depth of $10 \mathrm{~cm}$ can be attributed to a change in soil temperature. Accordingly, the soil temperature should be measured in a similar circumstance, helping to better interpret the reasons that correspond to any difference among treatments. In particular, the differences during the year in terms of snow cover in different gap size plots, but also the different amount of solar radiation during the summer, represent a key driver for the microbial activity and thus for the soil recovering processes, which should be a topic of research for the future.

One important issue that should be taken into account is that the tree which forms the gap remains for a longer time in the gap of the NCG, which results in a slow decomposition of woody material, leading to an increase of the nourishment of soil biota and available nutrients for macro- and microorganisms. In contrast, the man-made gaps (i.e., the CC treatment) are created by removing one or more trees, however, the stumps and roots remain in the ground (Muscolo et al. 2014). Previous studies demonstrated that the large-size gaps have different microclimates as compared to the small-size ones, which in turn led to prolong the return period as well as restoring the forest stands to the initial conditions (Muscolo et al. 2007, He et al. 2015). The current study hypothesis, stating that an increase in the biological and microbial activities in the topsoil was strongly influenced by the small canopy gaps, is not supported by analyzed data. Hence, full recovery did not take place in any of the treat- ments. However, the study on the recovery processes of compacted soil physical and chemical properties, due to heterogeneous conditions and miscellaneous successional trends at the treefall gaps in the oldgrowth forests, requires a longer time span than 5 years.

\section{Conclusion}

In this study, the effects of different canopy gaps to accelerate the recovery of soil physio-chemical and biological properties were investigated on compacted soil in the skid trails and compared to levels at the UND area after a five year period since the logging operations. The recovery values of soil physical, chemical, and biological properties were higher in NCG followed by DDC and CC treatments. Nevertheless, five years were not enough to allow for full recovery of soil physical, chemical, and biological properties to restore natural conditions as those in the UND area.

This study showed that the establishment of small-size gaps as a silvicultural treatment results in a faster "recovery" of soil physical, chemical, and ecological properties. Therefore, considering forest management implications based on mimicking the natural treefall gaps, it seems that forest managers should make an effort to apply the single tree selection method in a silvicultural regime, which would not allow the forest canopy to open widely and produce gaps with an area of $>200 \mathrm{~m}^{2}$. However, more studies are needed to understand if gaps with dimensions ranging between the interval of $>200 \mathrm{~m}^{2}$ to $<1600 \mathrm{~m}^{2}$ have the capacity for soil recovery and to what level of dynamics as compared to the tested gaps of $200 \mathrm{~m}^{2}$.

The remaining dead wood in the natural gaps may affect the organic matter and thus $\mathrm{C}$ and $\mathrm{N}$ as well as microbiological activity. Hence, further research should be conducted to determine the differences between the gap effect and dead wood effect. Further, simulating small-size gaps allows for a more complicated timber extraction, which can be performed only with a complex and dendritic skid trails network, resulting in highly extraction costs. Moreover, such silvicultural treatment requires high skilled forest operators both for felling and extraction operations. Designated skid trails should be used to at least limit soil compaction, thus preserving the rest of the area. When such a high-impact practice is unavoidable, careful technical surveillance during each phase of work should be carried out by people who are trained and adequately compensated. The application of all of these practices is required to reduce the impact on soil and the whole ecosystem.

\section{Acknowledgements}

We thank Dr. Bruno Ferry at AgroParisTech for his review of the draft manuscript and constructive comments and suggestions.

\section{References}

Bauhus J, Vor T, Bartsch N, Cowling A (2004). The effects of gaps and liming on forest floor decomposition and soil $\mathrm{C}$ and $\mathrm{N}$ dynamics in a Fagus sylvatica forest. Canadian Journal of Forest Research 34 (3): 509-518. - doi: 10.1139/x03218

Cambi M, Certini G, Fabiano F, Foderi C, Laschi A, Picchio R (2015). Impact of wheeled and tracked tractors on soil physical properties in a mixed conifer stand. iForest 9: 89-94. - doi: 10.3832/ifor1382-008

Canham CD, Denslow JS, Platt WJ, Runkle JR, Spies TA, White PS (1990). Light regimes be neath closed canopies and tree-fall gaps in temperate and tropical forests. Canadian Journal of Forest Research 20 (5): 620-631. - doi: 10.1139/x 90-084

Coates KD, Burton PJ (1997). A gap-based approach for development of silvicultural systems to address ecosystem management objectives. Forest Ecology and Management 99 (3): 337 354. - doi: 10.1016/S0378-1127(97)00113-8

Danielson RE, Southerland PL (1986). Methods of soil analysis. Part I. Physical and mineralogical methods ( $2^{\text {nd }}$ edn). ASA, Soil Science Society of America, Madison, WI, USA, pp. 443-46o.

Ebeling C, Lang F, Gaertig T (2016). Structural recovery in three selected forest soils after compaction by forest machines in Lower Saxony, Germany. Forest Ecology and Management 359 (1-3): 74-82. - doi: 10.1016/j.foreco.2015.09.045 Edwards CA, Bohlen PJ (1996). Biology and ecology of earthworms ( ${ }^{\text {rd }}$ edn). Chapman and Hall, London, UK, pp. 426. [online] URL: http:// books.google.com/books?id=ad4rDwD_GhsC

Field CB, Kaduk J (2004). The carbon balance of an old-growth forest: building across approaches. Ecosystems 7: 525-533. - doi: 10.1007/ s10021-004-0142-7

Gardiner B, Berry P, Moulia B (2016). Review: wind impacts on plant growth, mechanics and damage. Plant Science 245: 94-118. - doi: 10.1016 /j.plantsci.2016.01.006

Gee GW, Bauder JW (1986). Particle-size analysis. In: "Methods of Soil Analysis, Part 1. Physical and Mineralogical Methods" (Klute A ed). Soil Science Society of America, Madison, WI, pp. 383-411.

Goutal N, Keller T, Defossez P, Ranger J (2013). Soil compaction due to heavy forest traffic: measurements and simulations using an analytical soil compaction model. Annals of Forest Science 70 (5): 545-556. - doi: 10.1007/s13595013-0276-x

Hartmann M, Niklaus PA, Zimmermann S, Schmutz S, Kremer J, Abarenkov K, Lüscher P, Widmer F, Frey $B$ (2014). Resistance and resilience of the forest soil microbiome to logging-associated compaction. The ISME Journal 8 (1): 226244. - doi: 10.1038/ismej.2013.141

He Z, Liu J, Su S, Zheng S, Xu D, Wu Z, Hong W, Wang $L$ (2015). Effects of forest gaps on soil properties in Castanopsis kawakamii nature forest. PLoS One 10 (10): e0141203. - doi: 10.1371/ journal.pone.0141203

Hu B, Yang B, Pang X, Bao W, Tian G (2016). Responses of soil phosphorus fractions to gap size in a reforested spruce forest. Geoderma 279: 61-69. - doi: 10.1016/j.geoderma.2016.05.0 23 
Jourgholami M, Fathi K, Labelle ER (2018). Effects of foliage and traffic intensity on runoff and sediment in skid trails after trafficking in a deciduous forest. European Journal of Forest Research 137 (2): 223-235. - doi: 10.1007/s10342018-1102-7

Jourgholami M, Ghassemi T, Labelle ER (2019). Soil physio-chemical and biological indicators to evaluate the restoration of compacted soil following reforestation. Ecological Indicators 101 (4): 102-110. - doi: 10.1016/j.ecolind.2019.01. 009

Kemper WD, Rosenau RC (1986). Aggregate stability and size distribution. In: "Methods of Soil Analysis. Physical and Mineralogical Properties. Part I ( $2^{\text {nd }}$ edn)" (Klute A ed). Agronomy, vol. 9, ASA, Soil Science Society of America, Madison, WI, USA, pp. 425-442. [online] URL: http:// eprints.nwisrl.ars.usda.gov/id/eprint/732/3/585. pdf

Klaes B, Struck J, Schneider R, Schuler G (2016). Middle-term effects after timber harvesting with heavy machinery on a fine-textured forest soil. European Journal of Forest Research 135 (6): 1083-1095. - doi: 10.1007/s10342-016-0995-2 Kooch $\mathrm{Y}$, Zaccone C, Lamersdorf NP, Tonon G (2014). Pit and mound influence on soil features in an Oriental Beech (Fagus orientalis Lipsky) forest. European Journal of Forest Research 133 (2): 347-354. - doi: 10.1007/s10342-013-0766-

Latif ZA, Blackburn GA (2010). The effects of gap size on some microclimate variables during late summer and autumn in a temperate broadleaved deciduous forest. International Journal of Biometeorology 54 (2): 119-129. - doi: 10.1007/ s00484-009-0260-1

Lin N, Bartsch N, Heinrichs S, Vor T (2015). Longterm effects of canopy opening and liming on leaf litter production: and on leaf litter and fineroot decomposition in a European beech ( $\mathrm{Fa}$ gus sylvatica L.) forest. Forest Ecology and Management 338 (2): 183-190. - doi: 10.1016/j.for eco.2014.11.029

Liu Y, Zhang J, Yang W, Wu F, Xu Z, Tan B, Zhang L, He X, Guo L (2018). Canopy gaps accelerate soil organic carbon retention by soil microbial biomass in the organic horizon in a subalpine fir forest. Applied Soil Ecology 125: 169-176. - doi: 10.1016/j.apsoil.2018.01.002

Marchi E, Chung W, Visser R, Abbas D, Nordfiell T, Mederski PS, McEwan A, Brink M, Laschi A (2018). Sustainable Forest Operations (SFO): a new paradigm in a changing world and climate. Science of The Total Environment 634 (2): 13851397. - doi: 10.1016/j.scitotenv.2018.04.084 Merino A, Edeso JM, González MJ, Marauri P
(1998). Soil properties in a hilly area following different harvesting management practices. Forest Ecology and Management 103 (2-3): 235246. - doi: 10.1016/S0378-1127(97)00229-6

Meyer C, Luscher P, Schulin R (2014). Enhancing the regeneration of compacted forest soils by planting black alder in skid lane tracks. European Journal of Forest Research 133 (3): 453465. - doi: 10.1007/s10342-013-0776-0

Muscolo A, Sidari M, Mercurio R (2007). Influence of gap size on organic matter decomposition, microbial biomass and nutrient cycle in Calabrian pine (Pinus laricio Poiret) stands. Forest Ecology and Management 242 (2-3): 412418. - doi: 10.1016/j.foreco.2007.01.058

Muscolo A, Bagnato S, Sidari M, Mercurio R (2014). A review of the roles of forest canopy gaps. Journal of Forestry Research 25 (4): 725736. - doi: 10.1007/s11676-014-0521-7

Ni XY, Yang WQ, Tan B, He J, Xu LY, Li H, Wu FZ (2015). Accelerated foliar litter humification in forest gaps: dual feedbacks of carbon sequestration during winter and the growing season in an alpine forest. Geoderma 241-242: 136-144. doi: 10.1016/j.geoderma.2014.11.018

Özcan M, Gökbulak F (2015). Effect of size and surrounding forest vegetation on chemical properties of soil in forest gaps. iForest - Biogeosciences and Forestry 8 (1): 67-72. - doi: 10.3832/iforo940-007

Picchio R, Neri F, Petrini E, Verani S, Marchi E, Certini $G$ (2012). Machinery-induced soil compaction in thinning two pine stands in central Italy. Forest Ecology and Management 285: 3843. - doi: 10.1016/j.foreco.2012.08.008

Picchio R, Tavankar F, Nikooy M, Pignatti G, Venanzi R, Lo Monaco A (2019a). Morphology, growth and architecture response of beech (Fagus orientalis Lipsky) and Maple Tree (Acer velutinum Boiss.) seedlings to soil compaction stress caused by mechanized logging operations. Forests 10: 771. - doi: 10.3390/f10090771

Picchio R, Venanzi R, Tavankar F, Luchenti I, Iranparast Bodaghi A, Latterini F, Nikooy M, Di Marzio N, Naghdi R (2019b). Changes in soil parameters of forests after windstorms and timber extraction. European Journal of Forest Research 138: 875-888. - doi: 10.1007/s10342-01901210-5

Prescott CE (2002). The influence of the forest canopy on nutrient cycling. Tree Physiology 22 (15-16): 1193-1200. - doi: 10.1093/treephys/22.1516.1193

Rab MA (2004). Recovery of soil physical properties from compaction and soil profile disturbance caused by logging of native forest in Victorian central highlands, Australia. Forest Ecol- ogy and Management 191 (1-3): 329-340. - doi: 10.1016/j.foreco.2003.12.010

Ritter E (2005). Litter decomposition and nitrogen mineralization in newly formed gaps in a Danish beech (Fagus sylvatica) forest. Soil Biology and Biochemistry 37 (7): 1237-1247. - doi: 10.1016/j.soilbio.2004.11.020

Sariyildiz T (2008). Effects of gap-size classes on long-term litter decomposition rates of beech, oak and chestnut species at high elevations in northeast Turkey. Ecosystems 11 (6): 841-853. doi: 10.1007/s10021-008-9164-X

Scharenbroch BC, Bockheim JG (2008). Gaps and soil $C$ dynamics in old growth Northern Hardwood-Hemlock forests. Ecosystems 11 (3): 426441. - doi: 10.1007/s10021-008-9131-6

Scharenbroch BC, Bockheim JG (2011). Methods for studying treefall gaps: a review. Forest Ecology and Management 261 (7): 1143-1151. - doi: 10.1016/j.foreco.2011.01.011

Schliemann SA, Bockheim JG (2014). Influence of gap size on carbon and nitrogen biogeochemical cycling in Northern hardwood forests of the Upper Peninsula, Michigan. Plant and Soil 377 (1-2): 323-335. - doi: 10.1007/s11104-013-2005-5

Sefidi K, Marvie Mohadjer MR, Mosandl R, Copenheaver CA (2011). Canopy gaps and regeneration in old- growth Oriental beech (Fagus orientalis Lipsky) stands, northern Iran. Forest Ecology and Management 262 (6): 1094-1099. - doi: 10.1016/j.foreco.2011.06.008

Sierra J, Motisi N (2012). Shift in C and N humification during legume litter decomposition in an acid tropical ferralsol. Soil Research 50: 380389. - doi: 10.1071/SR12101

Thiel AL (2008). Nitrogen dynamics across silvicultural canopy gaps in young forests of western Oregon. M.Sc. Thesis, Department of Forest Science, Oregon State University, Corvallis, OR, USA, pp. 98.

Walkley A, Black IA (1934). An examination of the Degtjareff method for determining soil organic matter and a proposed modification of chromic acid titration method. Soil Science 37 (1): 29-38. - doi: 10.1097/00010694-19340100000003

Xu JX, Xue L, Su ZY (2016). Impacts of forest gaps on soil properties after a severe ice storm in a Cunninghamia lanceolata stand. Pedosphere 26 (3): 408-416. - doi: 10.1016/S1002-0160(15) 60053-4

Yang Y, Geng Y, Zhou H, Zhao G, Wang L (2017). Effects of gaps in the forest canopy on soil microbial communities and enzyme activity in a Chinese pine forest. Pedobiologia 61: 51-60. doi: 10.1016/j.pedobi.2017.03.001 